\title{
DETERMINANTS OF BENCHMARK INTEREST RATE: EVIDENCE FROM TURKISH BOND MARKETS
}

\section{DOI: 10.17261/Pressacademia.2020.1305}

JEFA- V.7-ISS.4-2020(2)-p.308-323

Mehmet Kuzu

Bayburt Universty, Department of Business Administration, Bayburt, Turkey. Mehmetkuzu86@gmail.com, ORCID:0000-0001-5354-4368

Date Received: September 9, $2020 \quad$ Date Accepted: November 29, 2020

To cite this document

Kuzu, M., (2020). Determinants of benchmark interest rate: evidence form Turkish bond markets. Journal of Economics, Finance and Accounting (JEFA), V.7(4), p.308-323.

Permenant link to this document: http://doi.org/10.17261/Pressacademia.2020.1305

Copyright: Published by PressAcademia and limited licensed re-use rights only.

\section{ABSTRACT}

Purpose- The aim of this study is to analyze the determinants of benchmark interest rate for Turkey that on framework of Turkey's economic and financial determinants of the political cycle of Turkey and examine their relationships and the interactions of indicators to determined benchmark interest rates.

Methodology- In this study, Augmented Dickey Fuller unit root test was applied to select the method by which long and short term relationships will be determined. Since the series are stationary at the same level, the VAR model was established and the short-term relationships were examined with the long-term vector error correction model with the Johansen cointegration test. Impulse-response analysis, variance decomposition and historical decomposition tests were carried out within the framework of the Granger test test in order to determine the interactions between variables.

Findings- The benchmark interest rate is balanced in the short and long term with the selected variables and the deviations in the short term can be corrected in the long term. The variables that affect the benchmark interest the most are gold, inflation and US 10-year bond rates. Conclusion- The sensitivity of the benchmark rate is high against the shock waves arising from gold prices, inflation and US 10-year bond rates. Central bank Weighted average funding cost is more determinant in the formation of market rates than real interest rates. In short, the central bank monetary policy, inflation expectations and interest rates and gold prices abroad determines the formation of market interest for Turkey.

Keywords: Benchmark rate, real interest, government bonds, VAR model, Johansen Cointegration Test.

JEL Codes: F37, G23, f39

\section{INTRODUCTION}

Benchmark interest; It refers to the secondary market interest of the Government Bond, which has 2 years to maturity and has a coupon payment every 3 months. This interest; TRT130515T11 is the interest of the government bond for Turkey. This interest is named as benchmark interest since it is taken as a reference for many transactions. Benchmark interest rate is a financial tool used to determine the base price of bonds. This interest rate is the market price of the bond that is bought and sold in the secondary market. The development of the bond markets is related to inflation rates.

Global financial system; The use of fund surpluses in advanced countries to emerging countries in return for capital gains has been structured within the framework of financial policy. In a sense, at the global level, it can be stated that investors carry their savings from financial markets where the cost of money is low to the markets where the cost is higher for capital gain.

The global financial political cycle, which became institutionalized in the 2000s, triggered financial and real sector crises in a certain period as a result of periodic structural financial fragilities in emerging market economies. As a result of these crises, the emerging market economies demanding credits from the creditors in advanced economies or the IMF caused the establishment of a dependency relationship between advanced and emerging markets economies.

The increase in interest rate hike expectations in advanced economies causes an increase pressure on the benchmark interest rates in emerging economies. The interest rate shocks that emerged with this pressure caused exchange rate and inflation shocks. In a sense, the factor that provides the systemic link between advanced and emerging market economies in the functioning of the global financial system is the benchmark interest rates in both country groups. Therefore, the expectation 
of an increase and increase in the benchmark interest rates of emerging countries reveals systemic risks that may cause financial and economic crises due to interest shocks in emerging markets. Identifying the determinants of the benchmark bond interest rate and their interactions is vital in monitoring, preventing and controlling these risks.

There are two main approaches in determining interest rates. These are real powers and monetarist approaches. Real power theory; tells that the rate of interest is determined by real factors. Real factors; It is based on the principle that savings supply and investment demand determine the interest rate in capital markets. According to Keynes' monetarist approach, interest is a purely monetary phenomenon. In this context, theories to explain interest rates; Classical interest theory, neo-classical creditable funds theory, Keynesian Liquidity preference approach, Neo Keynesian Hick-Hanse theory and Tobin portfolio theory. And also, Barr and Pesaran(1997), Calvo, Leiderman and Reinhart (1993), Dooley, Fernandez-Arias and Kletzer(1996) and Frankel (1994) maintain that changes in international interest rates have been a key factor influencing capital flows to emerging market countries in the 1990s.

There is a negative relationship between the price of bonds and interest rate. As the price of bonds increases, their interest decreases. Relatively high inflation in emerging economies decreases the value of bonds and causes the interest rates of bonds to increase. Therefore, investors in these markets demand nominal interest; They add a risk premium in addition to real interest and inflation expectations. Besides, role of various macroeconomic policies and fundamentals for the debt-crisis and provided the empirical rationale for using certain economic fundamentals in the determination of the risk-premium in international capital markets (Sachs, 1985). As a consequence of capital flows, the relations between stock and bond returns have positve sign in short time while the long-term stock-bond relation is significantly negative (Lin, Yang, Marsh and Chen, 2018).

This study in Turkey as an emerging market benchmark rate will be tried experimentally determined in accordance with structured theoretical framework determinants and interactions. This framework is based on the theoretical determinants of interest rates and the financial political cycle explained by the global financial system. Depended variable of the 2-year government bond interest was selected as the benchmark interest for Turkey. The Central Bank weighted average funding cost, real interest, inflation, USD / TL rate, real effective exchange rate, CDS (Credit Default Swap) and the US 10-year benchmark bond rate were selected as determining variables.

Johansen cointegration method has been used to perform long-term and short-term equilibrium analysis of independent variables with the dependent variable. Short-term equilibrium analysis was conducted with error correction model. The VAR model is established to determine the interactions of independent variables with the benchmark interest rate. Based on this model, granger/wald tes, variance decomposition, impulse-response analysis, and historical decomposition tests were performed.

With the variance decomposition method, the degree of explanation of the dependent variable periodically was determined. Then, the responses of the dependent variable to the shocks occurring in the independent variables were tested using impulse-response analysis. Extent of disclosure of the variables are calculated retroactively for Turkey with the historical decomposition method. The results obtained from these tests are explained in relation to each other. In addition, the obtained results were reviewed for Turkey in line with the theoretical framework of the subject.

\section{LITERATURE REVIEW}

Experimentally selected literature on government bond rates has generally emerged within the framework of the effect of interest rates in advanced economies on bonds in emerging market economies. The methodologies used are generally cointegration, VAR, ARCH-GARCH and panel data tests. Selected literature is summarized in the table below.

Table 1: Selected Literature

\begin{tabular}{|l|l|l|l|l|l|}
\hline Author & Term & Frequency & Country & Method & Findings \\
\hline $\begin{array}{l}\text { Demir and } \\
\text { Sever (2008) }\end{array}$ & $\begin{array}{l}1987- \\
2007\end{array}$ & Monthly & Turkey & $\begin{array}{l}\text { Johansen } \\
\text { Cointegration }\end{array}$ & $\begin{array}{l}\text { They found that there is a correct } \\
\text { relationship between the amount of } \\
\text { domestic debt and the interest rate. }\end{array}$ \\
\hline $\begin{array}{l}\text { Berument and } \\
\text { Malatyalı } \\
(1999\end{array}$ & $\begin{array}{l}1988- \\
1996\end{array}$ & Monthly & Turkey & $\begin{array}{l}\text { Arch And } \\
\text { Garch }\end{array}$ & $\begin{array}{l}\text { They found that nominal interest rates } \\
\text { increased in response to inflation risk, and } \\
\text { that there was an inandrse relationship } \\
\text { between borrowing maturity and interest } \\
\text { rates. }\end{array}$ \\
\hline
\end{tabular}




\begin{tabular}{|c|c|c|c|c|c|}
\hline $\begin{array}{l}\text { Masatçı and } \\
\text { Darıcı (2006) }\end{array}$ & $\begin{array}{l}1996- \\
2004\end{array}$ & Monthly & Turkey & $\begin{array}{l}\text { Johansen } \\
\text { Cointegration }\end{array}$ & $\begin{array}{l}\text { US Federal Reserand (Fed) interest rates, } \\
\text { interest rates could not be found in Turkey } \\
\text { a positiand impact on as expected. }\end{array}$ \\
\hline $\begin{array}{l}\text { Clare and } \\
\text { Lekkos (2000) }\end{array}$ & $\begin{array}{l}1979- \\
2000\end{array}$ & $\begin{array}{l}\text { Monthly } \\
\text { and Daily }\end{array}$ & $\begin{array}{l}\text { Germany, } \\
\text { England and } \\
\text { USA }\end{array}$ & VAR & $\begin{array}{l}\text { It has been found that the yield curands of } \\
\text { each of these markets are affected by } \\
\text { international factors. It has also been } \\
\text { obserandd that the impact of these factors } \\
\text { increases significantly in times of financial } \\
\text { crisis. }\end{array}$ \\
\hline $\begin{array}{l}\text { Norliza, } \\
\text { Muhammad } \\
\text { and Masron } \\
\text { (2009) }\end{array}$ & $\begin{array}{l}2001- \\
2008\end{array}$ & Monthly & Malasia & $\begin{array}{l}\text { Johansen } \\
\text { Cointegration }\end{array}$ & $\begin{array}{l}\text { Interest rates, CPI and industrial production } \\
\text { index haand a significant effect on } \\
\text { corporate bond yield spreads. }\end{array}$ \\
\hline $\begin{array}{l}\text { Şenkesen } \\
\text { (2009) }\end{array}$ & $\begin{array}{l}2003- \\
2008\end{array}$ & Monthly & Turkey & Reggression & $\begin{array}{l}\text { As a result of the analysis, it was reandaled } \\
\text { that inandstor sensitivity has a determining } \\
\text { effect on bond yields. }\end{array}$ \\
\hline $\begin{array}{l}\text { Rodionova } \\
\text { (2010) }\end{array}$ & $\begin{array}{l}2003- \\
2009\end{array}$ & Monthly & Russia & $\begin{array}{l}\text { Johansen } \\
\text { Cointegration } \\
\text { And Var }\end{array}$ & $\begin{array}{l}\text { According to the results of the study, } \\
\text { inflation and its expectations, exchange } \\
\text { rate and money supply increase explain less } \\
\text { than a third of the moandments of bond } \\
\text { returns. }\end{array}$ \\
\hline $\begin{array}{l}\text { Poghosyan, } \\
2014\end{array}$ & $\begin{array}{l}1980- \\
2010\end{array}$ & Daily & $\begin{array}{l}\text { Advanced } \\
\text { Economies }\end{array}$ & Cointegration & $\begin{array}{l}\text { In the short term, the changes in bond } \\
\text { yields deviate from the long-term balance } \\
\text { in response to changes in the positiand } \\
\text { effect of the debt / GDP ratio, the positiand } \\
\text { effect of real money market interest rates } \\
\text { and the negatiand effect of inflation. }\end{array}$ \\
\hline Yavuz (2012) & $\begin{array}{l}2002- \\
2010\end{array}$ & Monthly & Turkey & Garch & $\begin{array}{l}\mathrm{CPI} \text { and industrial production in Turkey is } \\
\text { one of about a third of the volatility of the } \\
\text { bond market in Turkey Analysis, Euro / } f \\
\text { exchange rate and reached results can be } \\
\text { explained by the volatility of the US bond } \\
\text { yields. }\end{array}$ \\
\hline $\begin{array}{l}\text { Chowdhury, } \\
\text { Bayar and Kılıç } \\
\text { (2013) }\end{array}$ & $\begin{array}{l}2000- \\
2009\end{array}$ & Monthly & $\begin{array}{l}\text { Emerging } \\
\text { markets } \\
\text { countries }\end{array}$ & Panel data & $\begin{array}{l}\text { The results of the analysis show that there } \\
\text { is a positiand relationship between the } \\
\text { bond index and foreign direct inandstments } \\
\text { and inflation, while there is a negatiand } \\
\text { relationship between the bond index and } \\
\text { GDP, total foreign debt stock. }\end{array}$ \\
\hline $\begin{array}{l}\text { Fen, Yee, Ling, } \\
\text { Cher and Yean } \\
(2014)\end{array}$ & $\begin{array}{l}1996- \\
2003\end{array}$ & Quarterly & Malasia & Ols & $\begin{array}{l}\text { According to the research results, there is a } \\
\text { positiand relationship between the short } \\
\text { term interest rate and the bond returns. }\end{array}$ \\
\hline $\begin{array}{l}\text { Lebedeff } \\
\text { (2014) }\end{array}$ & $\begin{array}{l}1997- \\
2011\end{array}$ & Daily & $\begin{array}{l}\text { Scandinavia } \\
\text { Countries }\end{array}$ & $\begin{array}{l}\text { Impulse- } \\
\text { Response }\end{array}$ & $\begin{array}{l}\text { It shows that US macroeconomic news has } \\
\text { a more pronounced effect oandrall than } \\
\text { news from European countries. We see that } \\
\text { the Finnish and Swedish goverment bond } \\
\text { markets responded the most to the } \\
\text { spilcreditdr effect of foreign } \\
\text { macroeconomic news. }\end{array}$ \\
\hline Hsing (2015) & $\begin{array}{l}1999- \\
2014\end{array}$ & Monthly & Spain & Egarch & $\begin{array}{l}\text { The analysis results in a higher gt debt to } \\
\text { GDP ratio, a higher treasury bill ratio, a } \\
\text { lower GDP growth rate, a higher expected } \\
\text { inflation rate, a higher US 10-year } \\
\text { goverment bond yield, a lower expected }\end{array}$ \\
\hline
\end{tabular}




\begin{tabular}{|l|l|l|l|l|l|}
\hline & & & & $\begin{array}{l}\text { nominal effectiand exchange rate, or the } \\
\text { goverment debt crisis caused the Spanish } \\
\text { goverment bond yield to rise. }\end{array}$ \\
\hline (Simoski,2019) & $\begin{array}{l}2000- \\
2020\end{array}$ & Monthly & $\begin{array}{l}\text { Emerging } \\
\text { Markets }\end{array}$ & $\begin{array}{l}\text { vector error } \\
\text { correction } \\
\text { (VEC) }\end{array}$ & $\begin{array}{l}\text { The obtained results from the models } \\
\text { estimated show that short-term interest } \\
\text { rates are the main drivers of longterm } \\
\text { government bond yields for all three } \\
\text { countries thus supporting Keynes's } \\
\text { conjectures in the } \\
\text { context of Latin American emerging } \\
\text { markets. }\end{array}$ \\
\hline $\begin{array}{l}\text { Ngo } \\
\text { etc.(2020) }\end{array}$ & Monthly & Vietnam & Egarch & $\begin{array}{l}\text { The findings of this study indicate that the } \\
\text { variation of Vietnam government bond } \\
\text { yields is in compliance with the theories of } \\
\text { term structure of interest rate. The results } \\
\text { also indicate that a proportion of the } \\
\text { variation in the yields on Vietnam } \\
\text { government bonds is attributed to the } \\
\text { interest rate itself in the previous period, } \\
\text { base rate, foreign interest rate, return of } \\
\text { the stock market, fiscal deficit, public debt, } \\
\text { and current account balance. }\end{array}$ \\
\hline
\end{tabular}

\section{THE THEORETICAL FRAMEWORK OF THE CONCEPT OF BONDS}

Bond; These are debt securities with a maturity of 1 year or more by public authorities or incorporated companes. Basic concepts about bonds; nominal (nominal) value, maturity, coupon rate and return to maturity concepts. The current price of the bond and the nominal price of the bond are different concepts. The current price of the bond changes constantly depending on the supply and demand of the bonds according to the conditions in the market.

The nominal price of the bond is the price that will be paid to the holder of the bond at the end of maturity. Nominal value represents the amount to be paid to the holder of the bond at maturity. Maturity; It is the time when the payment will be made to the holder of the bond. Coupon payments represent interim payments to be made. In other words, if the bond is held until the end of maturity, the return to the investor refers to the return to maturity. It is the interest rate that equates the present value of the payments obtained from the bond to the current market value. There is a negative relationship between the price of the bond and the interest rate.

Bonds can be classified as non-coupon bonds, coupon bonds and foreign exchange indexed bonds. Bonds without coupons are discount bonds. The price of the bond is less than its nominal value. Foreign Exchange Indexed Bonds are bonds that can be issued in indexed to foreign currency during inflationary periods. Coupon bonds; are divided into 3 as discounted, premium and break-even bonds.

Table 2: Types of Coupon Bonds

\begin{tabular}{|l|l|l|}
\hline COUPON BOND TYPES & PRICE & PRICE YIELD \\
\hline Discount Bond & Present price $<$ nominal value & Yield to maturity > coupon rate \\
\hline Premium Bond & Present price $>$ nominal value & Yield to maturity < coupon rate \\
\hline Breakeven Bond & Present price $=$ nominal value & Yield to maturity = coupon rate \\
\hline
\end{tabular}

The theoretical discussion of the experimental results should be done around the factors affecting the demand and supply of the bond. When the demand and supply curve of the bond come together, we find the equilibrium price and interest rate of the bond in the bond market. Equilibrium bond price is found by equating the amount of bonds offered to the amount of bonds demanded. 
Table 3: Factors Affecting Bond Demand and Supply

\begin{tabular}{|l|c|c|c|}
\hline FACTORS AFFECTING DEMAND & DEMAND & BOND PRICE & BOND INTEREST \\
\hline Fortune & + & + & - \\
\hline Expected Return & + & + & - \\
\hline Liquidity & + & - & + \\
\hline Risk & - & - & + \\
\hline Inflation Expectations & - & BOND PRICE & BOND INTEREST \\
\hline FACTORS AFFECTING THE SUPPLY & SUPPLY & - & + \\
\hline Profitability of Investments & + & - & + \\
\hline Budget Deficit & + & - & + \\
\hline Inflation Expectations & + & & \\
\hline
\end{tabular}

\section{DATA AND METHODOLOGY}

In the study, Augmented Dickey Fuller, Johansen cointegration, vector error correction model, Granger Block externality test, impulse-response analysis, variance decomposition and historical decomposition methods were used.

The level at which the variables become stationary is examined with the Dickey Fuller test. The long-term relationship between series stationary at the same level is investigated with the help of the Johansen cointegration test. In the study, johansen test was used instead of ARDL model because time series became stationary in their first differences.

When examining the stationarity of the series, two hypotheses are established. (Augmented- Dickey Fuller, 1979) These hypotheses can be expressed as follows.

HO: Time series contain unit root.

H1: Time series do not contain unit root.

In this context, $\mathrm{HO}$, which is the null hypothesis that expresses that time series at the level value contains unit root, was accepted at the 0.05 significance level for all time series. The $\mathrm{H} 1$ hypothesis stating that the series do not contain unit roots was rejected. Therefore, the first difference of the series is taken. Time series h0, which is the null hypothesis stating that the first difference value contains unit root, was rejected at the 0.05 significance level for all series. The h1 hypothesis, which states that the series do not contain unit roots, was accepted.

After the long and short term equilibrium analysis, a model was established in the first difference values within the framework of the unit root test results in order to determine the interaction between variables (Brooks, 2014).

With the variance decomposition, it is determined which variable is the most effective on a time series; Whether this variable, which is found to be effective, can be used as a policy tool is determined by impulse-response functions. Action-response functions; It is a method that reflects the effect of a standard error shock that will occur in one of the random error terms on the present and future values of the internal variables. (Özgen and Güloğlu, 2004: 97, Barışık and Kesikoğlu, 2006: 71).

Whether the long-run model works or not, short-run relationships and short-run deviations from balance are analyzed with the error correction model. After short and long term relationships, interactions between variables are examined with the VAR model. Accordingly, Granger Block Externality test was conducted to determine the internal and external variables among the variables. Accordingly, the order of the variables was determined and the periodic weight of the variables in explaining the dependent variables was examined using variance and historical decomposition models. With the impactresponse analysis, the status of the variables to be policy variability was examined.

In the study, as a benchmark interest rate of 2-year government bonds turkey is chosen. The theoretical framework that is drawn to this variable we examined the interaction, the annual inflation (CPI), the real effective exchange rate index, USD / TRY rate, real interest rates, gold prices (International), US 10-year government bond yield „, Central Bank of the Republic of Turkey Weighted average funding cost and CDS premiums variables are included in the analysis. Information on the Data Set is summarized on the table. 
Table 4: Data Set

\begin{tabular}{|l|l|l|l|l|}
\hline VARIABLE & CODE & TERM & FREQUENCY & SOURCE \\
\hline Benchmark Interest & TR2YBOND & $2011.02-2020.07$ & Monthly & Investing.Com \\
\hline US 10-Year Bond Interest & US1OYBOND & $2011.02-2020.07$ & Monthly & Investing.Com \\
\hline Cent. Bank. Net. Fund cost. & TCBWFR & $2011.02-2020.07$ & Monthly & Tcmb \\
\hline Real effective exchange rate & REEXR & $2011.02-2020.07$ & Monthly & Tcmb \\
\hline Gold (Logarithmic) & LOGGOLD & $2011.02-2020.07$ & Monthly & Investing.Com \\
\hline Credit Default Swap & CDS & $2011.02-2020.07$ & Monthly & Investing.Com \\
\hline Annual inflation (CPI & CPI & $2011.02-2020.07$ & Monthly & Tcmb \\
\hline USD / TL & US_TL_EXC & $2011.02-2020.07$ & Monthly & Investing.Com \\
\hline $\begin{array}{l}\text { Real Interest (According to the CPI } \\
\text { and Benchmark Interest }\end{array}$ & REINT & $2011.02-2020.07$ & Monthly & $\begin{array}{l}\text { Investing.Com, } \\
\text { Tcmb }\end{array}$ \\
\hline
\end{tabular}

\section{Figure 1: Graps of Data}

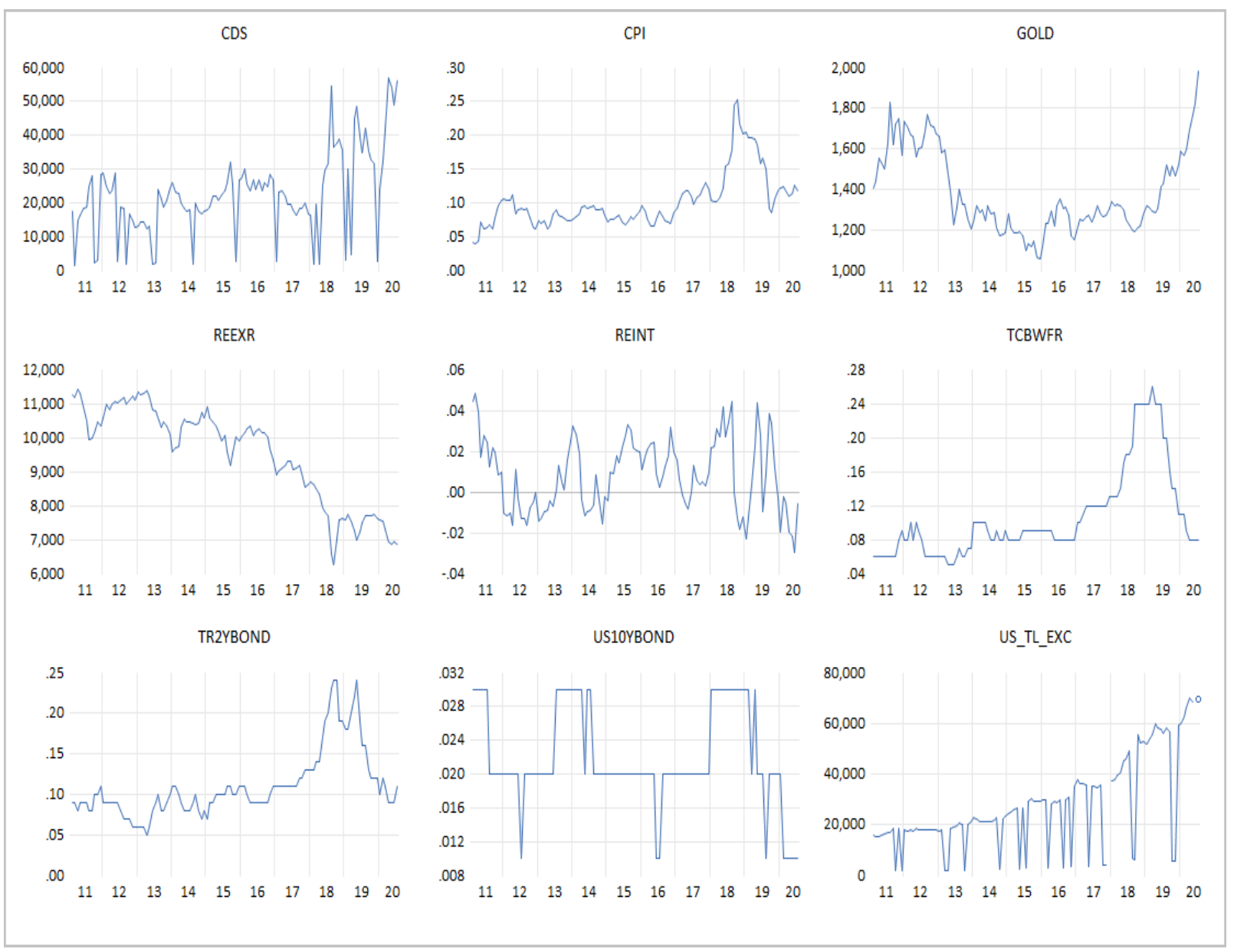

\section{FINDINGS AND DISCUSSIONS}

According to Augmented Dickey Fuller Test results, all series become stationary at the first difference level. In the creation of unit root test models, T statistic value was selected for the appropriate lag length, and models containing trend and constant terms were not selected. Since the variables are stationary at the same level, the Johansen cointegration test, which is structured at level values, is performed in the next step. 
Table 5: Results of Unit Root Tests

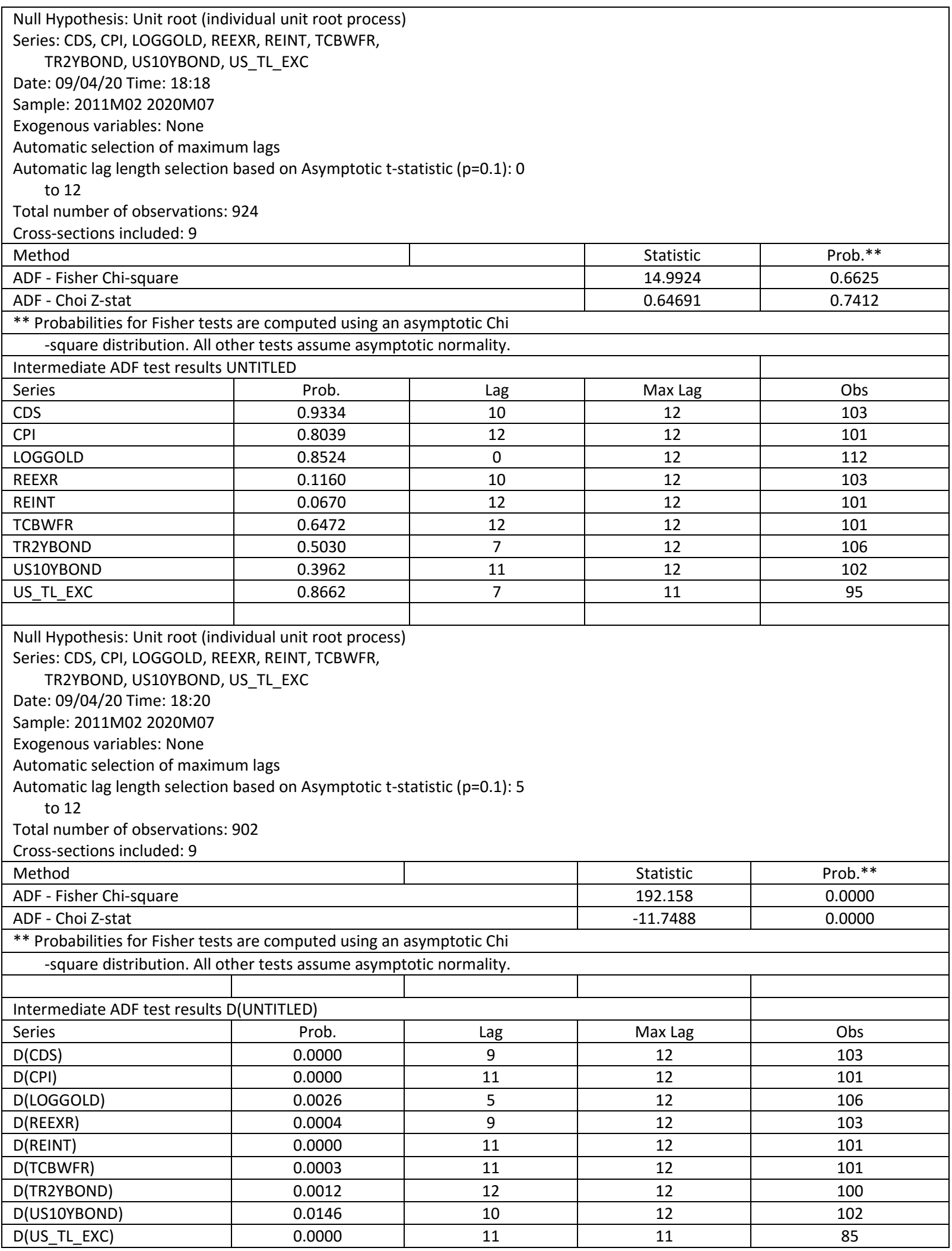


In order to establish the var model for the cointegration test, the appropriate lag length was selected according to the LR criteria information criteria.

Table 6: Selection of Lag Lenght

\begin{tabular}{|c|c|c|c|c|c|c|}
\hline \multicolumn{7}{|c|}{$\begin{array}{l}\text { VAR Lag Order Selection Criteria } \\
\text { Endogenous variables: TR2YBON } \\
\text { Exogenous variables: } \\
\text { Date: 09/04/20 Time: } 23: 17 \\
\text { Sample: } 2011 \mathrm{M} 02 \text { 2020M07 } \\
\text { Included observations: } 101\end{array}$} \\
\hline Lag & LogL & LR & FPE & AIC & $\mathrm{SC}$ & $\mathrm{HQ}$ \\
\hline 1 & -770.4069 & NA & $0.000170^{*}$ & 16.85954 & $18.95682^{*}$ & $17.70858^{*}$ \\
\hline 2 & -689.4061 & 133.1301 & 0.000176 & $16.85953^{*}$ & 21.05408 & 18.55760 \\
\hline 3 & -636.3457 & 77.75182 & 0.000333 & 17.41279 & 23.70461 & 19.95990 \\
\hline 4 & -565.5185 & 91.16378 & 0.000485 & 17.61423 & 26.00333 & 21.01038 \\
\hline 5 & -467.4923 & $108.7023 *$ & 0.000472 & 17.27708 & 27.76345 & 21.52226 \\
\hline $\begin{array}{l}\text { * indica } \\
\text { LR: seq } \\
\text { FPE: Fin } \\
\text { AIC: Ak: } \\
\text { SC: Sch } \\
\text { HQ: HaI }\end{array}$ & $\begin{array}{l}\text { g order selec } \\
\text { I modified L } \\
\text { diction erro } \\
\text { formation c } \\
\text { nformation } \\
\text { Quinn inform } \\
\end{array}$ & $\begin{array}{l}\text { the criterion } \\
\text { tatistic (each }\end{array}$ & $5 \%$ level) & & & \\
\hline
\end{tabular}

In the 5th lag length, a cointegration model including deterministic trend and constant term is used. According to the results, 4 cointegration vectors according to trace values and 3 cointegration vectors according to max eigen values were determined.

\section{Table 7: Results of Johansen Cointegration Test}

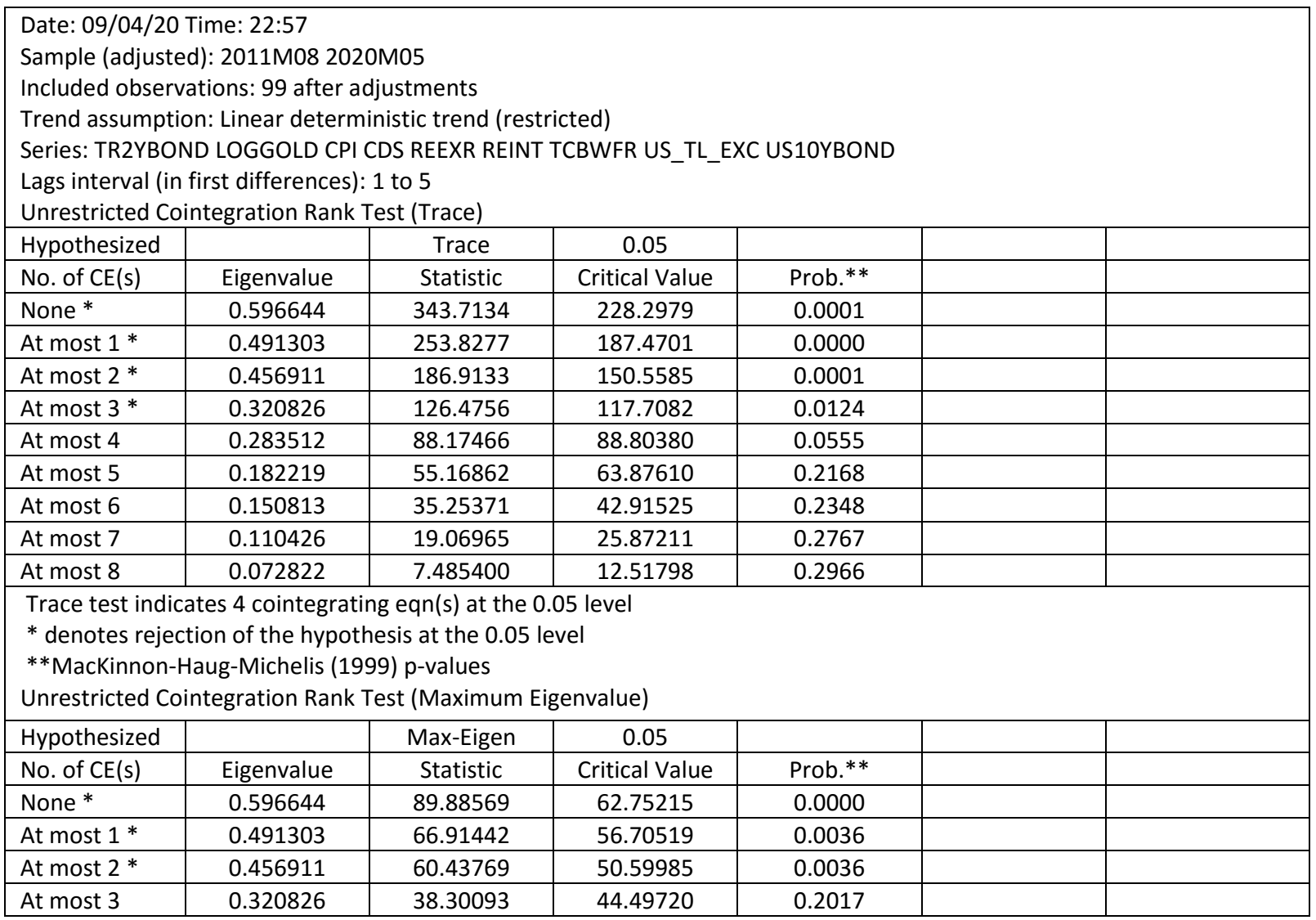




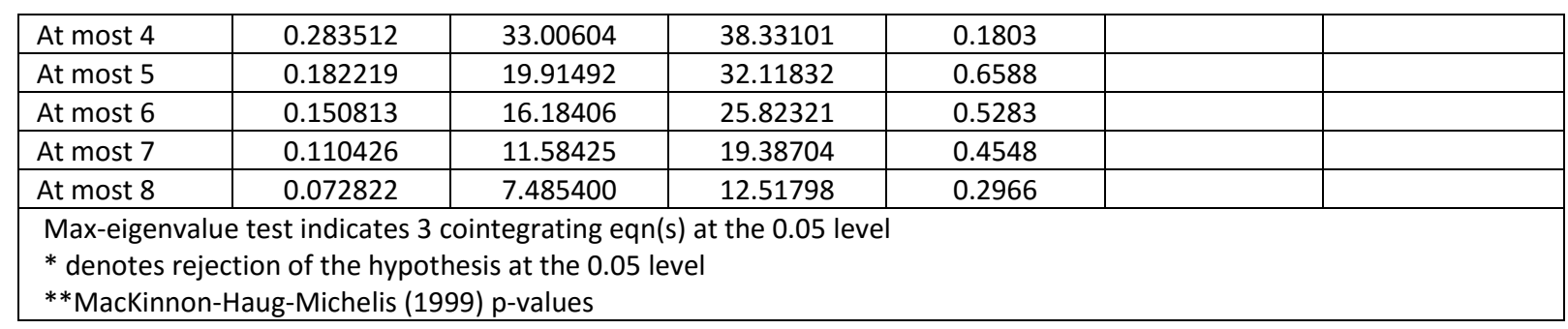

Cointegration equation and long-term coefficients are estimated within the scope of cointegration vectors. The coefficients of gold, CDS, real exchange rate, Central Bank weighted average interest, US 10-year bond interest and trend variable coefficients are positive and other variables have negative coefficients. According to T values, the coefficients of gold, CDS, real interest, Central Bank interest, dollar rate and trend variable are statistically significant.

Table 8: Coefficents of Cointegration Test

\begin{tabular}{|c|c|}
\hline Cointegrating Eq. & CointEq1 \\
\hline TR2YBOND(-1) & 1.000000 \\
\hline \multirow[t]{3}{*}{ LOGGOLD(-1) } & 0.284796 \\
\hline & $(0.05939)$ \\
\hline & [ 4.79542] \\
\hline \multirow[t]{3}{*}{$\mathrm{CPI}(-1)$} & -7.665373 \\
\hline & $(1.04590)$ \\
\hline & {$[-7.32896]$} \\
\hline \multirow[t]{3}{*}{$\operatorname{CDS}(-1)$} & 3.87E-06 \\
\hline & (1.4E-06) \\
\hline & [ 2.86128] \\
\hline \multirow[t]{3}{*}{ REEXR(-1) } & $2.22 \mathrm{E}-05$ \\
\hline & $(1.8 \mathrm{E}-05)$ \\
\hline & [ 1.20666] \\
\hline \multirow[t]{3}{*}{ REINT(-1) } & -5.435786 \\
\hline & $(1.01105)$ \\
\hline & {$[-5.37639]$} \\
\hline \multirow[t]{3}{*}{ TCBWFR(-1) } & 5.408285 \\
\hline & $(0.78301)$ \\
\hline & [ 6.90706] \\
\hline \multirow[t]{3}{*}{ US_TL_EXC(-1) } & $-5.21 \mathrm{E}-06$ \\
\hline & (1.4E-06) \\
\hline & {$[-3.71532]$} \\
\hline \multirow[t]{3}{*}{ US10YBOND(-1) } & 3.034315 \\
\hline & $(1.41301)$ \\
\hline & [ 2.14742] \\
\hline \multirow[t]{3}{*}{ @TREND(11M02) } & 0.001470 \\
\hline & $(0.00071)$ \\
\hline & [ 2.07183] \\
\hline C & -2.229428 \\
\hline $\begin{array}{l}(* * * * *) \text { standart errors } \\
{[* * * *] T \text { statistics value }}\end{array}$ & \\
\hline
\end{tabular}

An error correction model was established to test the model in the short term. With the error correction model, it was investigated whether the deviations that will occur from the balance in the short term reach the balance in the long term. The model was created with reference to max eigen values. Accordingly, since there are 3 cointegration vectors, error correction term coefficient coefficients should be negative and statistically significant. It fulfills this condition according to the estimated parameters. Among the error correction terms, 2-year benchmark interest, real interest and central bank 
interest are statistically significant. Inflation, real exchange rate and dollar rate variables are positive and other variables are negative. In the next step, block externality, variance decomposition, impulse-response analysis and historical decomposition methods were used to determine the interactions between variables.

Table 9: Coefficents of Error Correction Models

\begin{tabular}{|l|c|c|c|}
\hline Error Correction & CointEq1 & Standart Errors & T statistic \\
\hline D(TR2YBOND) & -0.122333 & $(0.03975)$ & {$[-3.07778]$} \\
\hline D(LOGGOLD) & -0.355104 & $(0.17886)$ & {$[-1.98543]$} \\
\hline D(CPI) & 0.020849 & $(0.04388)$ & {$[0.47518]$} \\
\hline D(CDS) & -70267.57 & $(36307.4)$ & {$[-1.93535]$} \\
\hline D(REEXR) & 8.012 .264 & -998.211 & {$[0.80266]$} \\
\hline D(REINT) & -0.147636 & $(0.03819)$ & {$[-3.86618]$} \\
\hline D(TCBWFR) & -0.129862 & $(0.03387)$ & {$[-3.83416]$} \\
\hline D(US_TL_EXC) & 72718.77 & $(48963.4)$ & {$[1.48516]$} \\
\hline D(US1OYBOND) & -0.023129 & $(0.01293)$ & {$[-1.78926]$} \\
\hline
\end{tabular}

According to unit root tests, the variables are stationary at the 1st difference values. For this reason, the 1st difference levels of the Var model variables were used. First, the appropriate lag length has been tried to be determined. 4 . The assumptions of the Var in Lag model are provided (Brooks,2014).

\section{Table 10: Lag Length Selection for Var Model Established with First Differences}

VAR Lag Order Selection Criteria

Endogenous variables: $D(T R 2 Y B O N D) D(C D S) D(C P I) D($ LOGGOLD) $D$ (REEXR) $D(R E I N T) D(T C B W F R) D(U S 10 Y B O N D)$

D(US_TL_EXC)

Exogenous variables: $\mathrm{C}$

Date: 09/04/20 Time: 23:48

Sample: 2011M02 2020M07

Included observations: 99

\begin{tabular}{|c|c|c|c|c|c|c|}
\hline Lag & LogL & LR & FPE & AIC & SC & HQ \\
\hline 0 & -924.6656 & NA & 0.001257 & 18.86193 & $19.09785^{*}$ & $18.95739^{*}$ \\
\hline 1 & -807.8522 & 210.0282 & $0.000614^{*}$ & 18.13843 & 20.49763 & 19.09296 \\
\hline 2 & -735.0018 & 117.7380 & 0.000751 & 18.30307 & 22.78555 & 20.11669 \\
\hline 3 & -659.8551 & 107.7862 & 0.000933 & 18.42132 & 25.02707 & 21.09402 \\
\hline 4 & -561.8999 & $\mathbf{1 2 2 . 6 9 1 4 *}$ & 0.000809 & $18.07879^{*}$ & 26.80782 & 21.61057 \\
\hline 5 & -501.1471 & 65.04845 & 0.001732 & 18.48782 & 29.34014 & 22.87869 \\
\hline
\end{tabular}

* indicates lag order selected by the criterion

LR: sequential modified LR test statistic (each test at $5 \%$ level)

FPE: Final prediction error

AIC: Akaike information criterion

SC: Schwarz information criterion

HQ: Hannan-Quinn information criterion

\section{Table 11: Results of Var Model Assumption Tests}

\begin{tabular}{|l|c|}
\hline AR ROOT (Modulus & $0,88-0,13$ \\
\hline PORTMENTAU AUTOCORELATION (probability & 0,0 \\
\hline NORMALITY (Jacque Barea, inverse hypothesis. probability) & $-0,48$ \\
\hline HETERODASTICY (chi square test, inverse hypothesis, probability) & 0,18 \\
\hline
\end{tabular}

As a reference, the wald test was applied to test causality and block externality at $5 \%$ and $10 \%$ levels. Based on the results obtained, it is concluded that the benchmark interest is internal and other variables are exogenous. 


\section{Table 11.Wald Test}

\begin{tabular}{|c|c|c|c|}
\hline $\begin{array}{l}\text { VAR Granger CaL } \\
\text { Date: 09/04/20 } \\
\text { Sample: } 2011 \mathrm{M0} \\
\text { Included observa }\end{array}$ & & & \\
\hline Dependent varia & & & \\
\hline Excluded & Chi-sq & $d f$ & Prob. \\
\hline $\mathrm{D}(\mathrm{CDS})$ & 4.205315 & 4 & 0.3789 \\
\hline $\mathrm{D}(\mathrm{CPI})$ & 10.21416 & 4 & 0.0370 \\
\hline $\mathrm{D}$ (LOGGOLD) & 15.41639 & 4 & 0.0039 \\
\hline $\mathrm{D}$ (REEXR) & 3.694171 & 4 & 0.4490 \\
\hline $\mathrm{D}$ (REINT) & 4.783512 & 4 & 0.3102 \\
\hline $\mathrm{D}$ (TCBWFR) & 9.976218 & 4 & 0.0408 \\
\hline D(US10YBOND) & 7.402005 & 4 & 0.1161 \\
\hline D(US_TL_EXC) & 11.85696 & 4 & 0.0184 \\
\hline All & 72.99420 & 32 & 0.0000 \\
\hline Dependent varia & & & \\
\hline Excluded & Chi-sq & $\mathrm{df}$ & Prob. \\
\hline $\mathrm{D}$ (TR2YBOND) & 5.038748 & 4 & 0.2833 \\
\hline $\mathrm{D}(\mathrm{CPI})$ & 6.102921 & 4 & 0.1916 \\
\hline $\mathrm{D}$ (LOGGOLD) & 4.234535 & 4 & 0.3752 \\
\hline D(REEXR) & 13.14825 & 4 & 0.0106 \\
\hline $\mathrm{D}$ (REINT) & 6.050511 & 4 & 0.1954 \\
\hline D(TCBWFR) & 16.54254 & 4 & 0.0024 \\
\hline D(US10YBOND) & 2.993819 & 4 & 0.5589 \\
\hline D(US_TL_EXC) & 5.824938 & 4 & 0.2126 \\
\hline All & 64.45845 & 32 & 0.0006 \\
\hline Dependent varia & & & \\
\hline Excluded & Chi-sq & $\mathrm{df}$ & Prob. \\
\hline $\mathrm{D}$ (TR2YBOND) & 2.612159 & 4 & 0.6247 \\
\hline $\mathrm{D}(\mathrm{CDS})$ & 9.339441 & 4 & 0.0532 \\
\hline $\mathrm{D}$ (LOGGOLD) & 6.461441 & 4 & 0.1672 \\
\hline $\mathrm{D}$ (REEXR) & 16.50454 & 4 & 0.0024 \\
\hline $\mathrm{D}$ (REINT) & 2.811187 & 4 & 0.5899 \\
\hline $\mathrm{D}$ (TCBWFR) & 10.23513 & 4 & 0.0366 \\
\hline $\mathrm{D}$ (US10YBOND) & 1.503212 & 4 & 0.8261 \\
\hline D(US_TL_EXC) & 5.645856 & 4 & 0.2272 \\
\hline All & 60.56941 & 32 & 0.0017 \\
\hline Dependent varia & & & \\
\hline Excluded & Chi-sq & $\mathrm{df}$ & Prob. \\
\hline $\mathrm{D}$ (TR2YBOND) & 3.803314 & 4 & 0.4333 \\
\hline $\mathrm{D}(\mathrm{CDS})$ & 3.034725 & 4 & 0.5520 \\
\hline $\mathrm{D}(\mathrm{CPI})$ & 4.917517 & 4 & 0.2959 \\
\hline D(REEXR) & 4.252658 & 4 & 0.3729 \\
\hline $\mathrm{D}$ (REINT) & 5.474941 & 4 & 0.2419 \\
\hline $\mathrm{D}$ (TCBWFR) & 2.068496 & 4 & 0.7232 \\
\hline $\mathrm{D}$ (US10YBOND) & 4.749355 & 4 & 0.3140 \\
\hline D(US_TL_EXC) & 2.634527 & 4 & 0.6207 \\
\hline All & 29.59256 & 32 & 0.5889 \\
\hline Dependent varia & & & \\
\hline Excluded & Chi-sq & df & Prob. \\
\hline $\mathrm{D}$ (TR2YBOND) & 4.176662 & 4 & 0.3826 \\
\hline $\mathrm{D}(\mathrm{CDS})$ & 2.773780 & 4 & 0.5964 \\
\hline $\mathrm{D}(\mathrm{CPI})$ & 3.175610 & 4 & 0.5289 \\
\hline
\end{tabular}




\begin{tabular}{|c|c|c|c|}
\hline $\mathrm{D}($ LOGGOLD) & 5.735437 & 4 & 0.2198 \\
\hline $\mathrm{D}$ (REINT) & 5.164807 & 4 & 0.2708 \\
\hline D(TCBWFR) & 5.535830 & 4 & 0.2366 \\
\hline D(US10YBOND) & 5.524373 & 4 & 0.2376 \\
\hline D(US_TL_EXC) & 5.195080 & 4 & 0.2679 \\
\hline All & 37.94123 & 32 & 0.2167 \\
\hline \multicolumn{4}{|c|}{ Dependent variable: $\mathrm{D}(\mathrm{REINT})$} \\
\hline Excluded & Chi-sq & df & Prob. \\
\hline $\mathrm{D}$ (TR2YBOND) & 2.163181 & 4 & 0.7058 \\
\hline $\mathrm{D}(\mathrm{CDS})$ & 2.914421 & 4 & 0.5722 \\
\hline $\mathrm{D}(\mathrm{CPI})$ & 2.572335 & 4 & 0.6317 \\
\hline $\mathrm{D}($ LOGGOLD) & 5.986557 & 4 & 0.2002 \\
\hline $\mathrm{D}$ (REEXR) & 5.576077 & 4 & 0.2331 \\
\hline D(TCBWFR) & 6.969830 & 4 & 0.1375 \\
\hline D(US10YBOND) & 1.180201 & 4 & 0.8813 \\
\hline D(US_TL_EXC) & 2.235588 & 4 & 0.6925 \\
\hline All & 36.38459 & 32 & 0.2718 \\
\hline \multicolumn{4}{|c|}{ Dependent variable: $\mathrm{D}$ (TCBWFR) } \\
\hline Excluded & Chi-sq & $\mathrm{df}$ & Prob. \\
\hline $\mathrm{D}$ (TR2YBOND) & 3.429657 & 4 & 0.4887 \\
\hline $\mathrm{D}(\mathrm{CDS})$ & 5.189175 & 4 & 0.2684 \\
\hline $\mathrm{D}(\mathrm{CPI})$ & 0.470122 & 4 & 0.9763 \\
\hline $\mathrm{D}($ LOGGOLD) & 2.206224 & 4 & 0.6979 \\
\hline $\mathrm{D}$ (REEXR) & 4.299448 & 4 & 0.3670 \\
\hline $\mathrm{D}(\mathrm{REINT})$ & 0.430807 & 4 & 0.9799 \\
\hline D(US10YBOND) & 2.812523 & 4 & 0.5897 \\
\hline D(US_TL_EXC) & 2.604055 & 4 & 0.6261 \\
\hline All & 72.43549 & 32 & 0.0001 \\
\hline \multicolumn{4}{|c|}{ Dependent variable: $\mathrm{D}($ US10YBOND) } \\
\hline Excluded & Chi-sq & $\mathrm{df}$ & Prob. \\
\hline $\mathrm{D}$ (TR2YBOND) & 1.717716 & 4 & 0.7875 \\
\hline $\mathrm{D}(\mathrm{CDS})$ & 12.02932 & 4 & 0.0171 \\
\hline $\mathrm{D}(\mathrm{CPI})$ & 4.349590 & 4 & 0.3608 \\
\hline $\mathrm{D}($ LOGGOLD) & 8.153120 & 4 & 0.0861 \\
\hline $\mathrm{D}$ (REEXR) & 2.758867 & 4 & 0.5990 \\
\hline $\mathrm{D}$ (REINT) & 3.405027 & 4 & 0.4925 \\
\hline $\mathrm{D}(\mathrm{TCBWFR})$ & 8.919555 & 4 & 0.0631 \\
\hline D(US_TL_EXC) & 4.790207 & 4 & 0.3095 \\
\hline All & 46.46200 & 32 & 0.0474 \\
\hline \multicolumn{4}{|c|}{ Dependent variable: D(US_TL_EXC) } \\
\hline Excluded & Chi-sq & $\mathrm{df}$ & Prob. \\
\hline $\mathrm{D}$ (TR2YBOND) & 2.826535 & 4 & 0.5873 \\
\hline $\mathrm{D}(\mathrm{CDS})$ & 3.717382 & 4 & 0.4456 \\
\hline $\mathrm{D}(\mathrm{CPI})$ & 5.095867 & 4 & 0.2776 \\
\hline $\mathrm{D}($ LOGGOLD) & 4.127225 & 4 & 0.3891 \\
\hline $\mathrm{D}$ (REEXR) & 2.247607 & 4 & 0.6903 \\
\hline $\mathrm{D}$ (REINT) & 4.468176 & 4 & 0.3463 \\
\hline $\mathrm{D}(\mathrm{TCBWFR})$ & 2.351320 & 4 & 0.6714 \\
\hline D(US10YBOND) & 0.461209 & 4 & 0.9772 \\
\hline All & 41.00049 & 32 & 0.1323 \\
\hline
\end{tabular}


Figure 2: Granger/Wald Tests Scheme

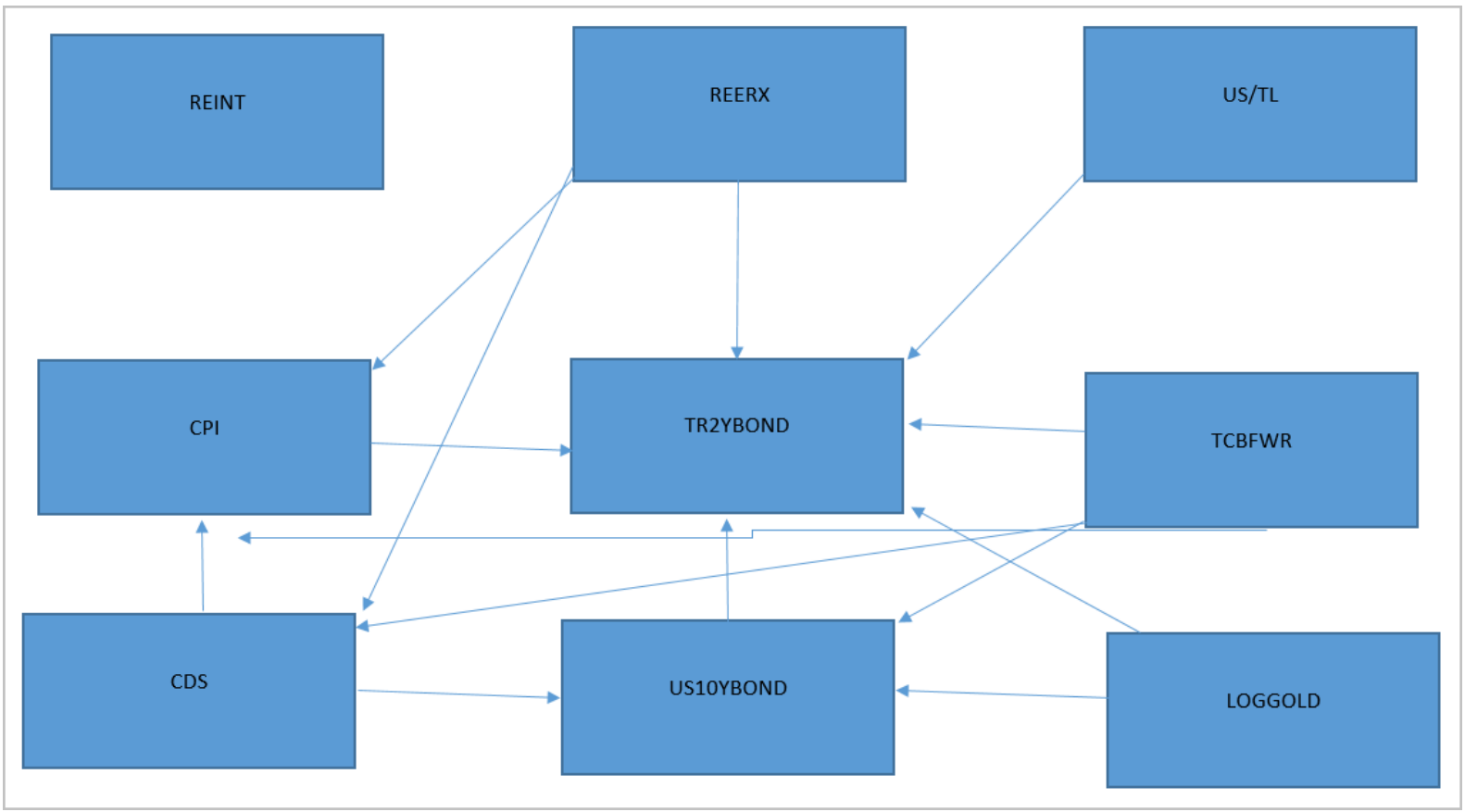

According to the results of variance decomposition, the explanation percentages of the dependent variable are excluded from their effects; gold, inflation, US 10-year bond interest, dollar rate, central bank interest and CDS.

Figue 3: Variance Decomposition Results

Variance Decomposition using Cholesky (d.f. adjusted) Factors

Variance Decomposition of D(TR2YBOND)

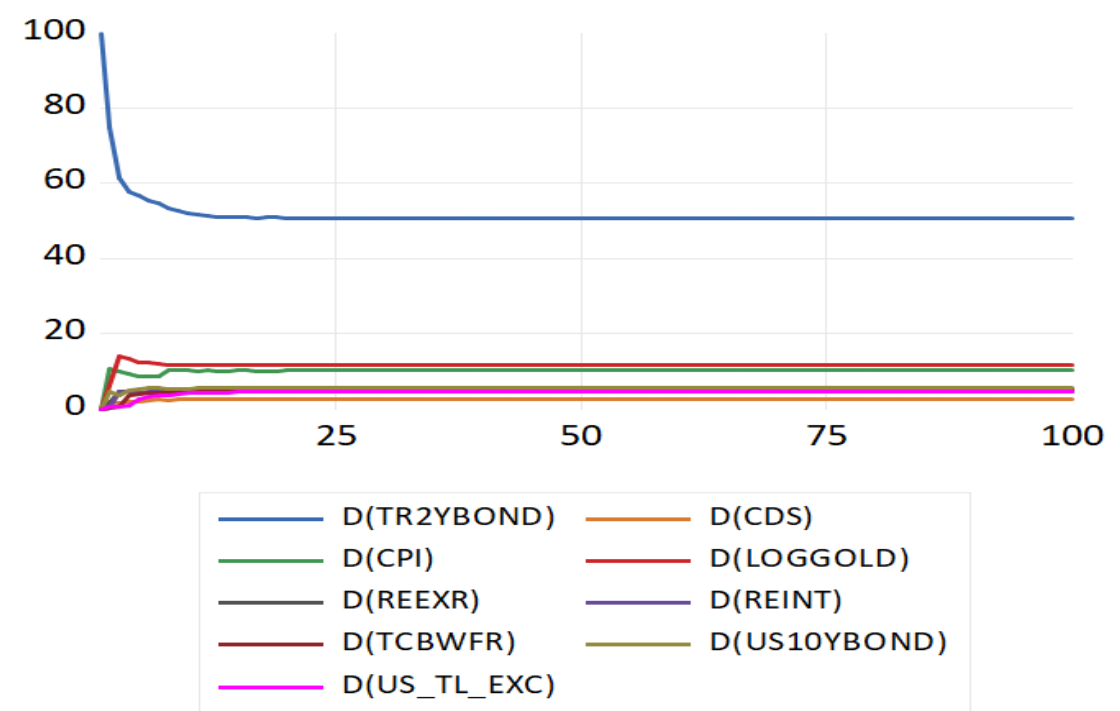

According to the results of the impulse-response analysis, the benchmark bond interest was most affected by inflation, the US 10-year bond interest and the dollar exchange rate shocks, respectively. Shocks occurring over all variables are neutralized after about 19 months. 
Figure 4: Impulse-Response Analysis Results

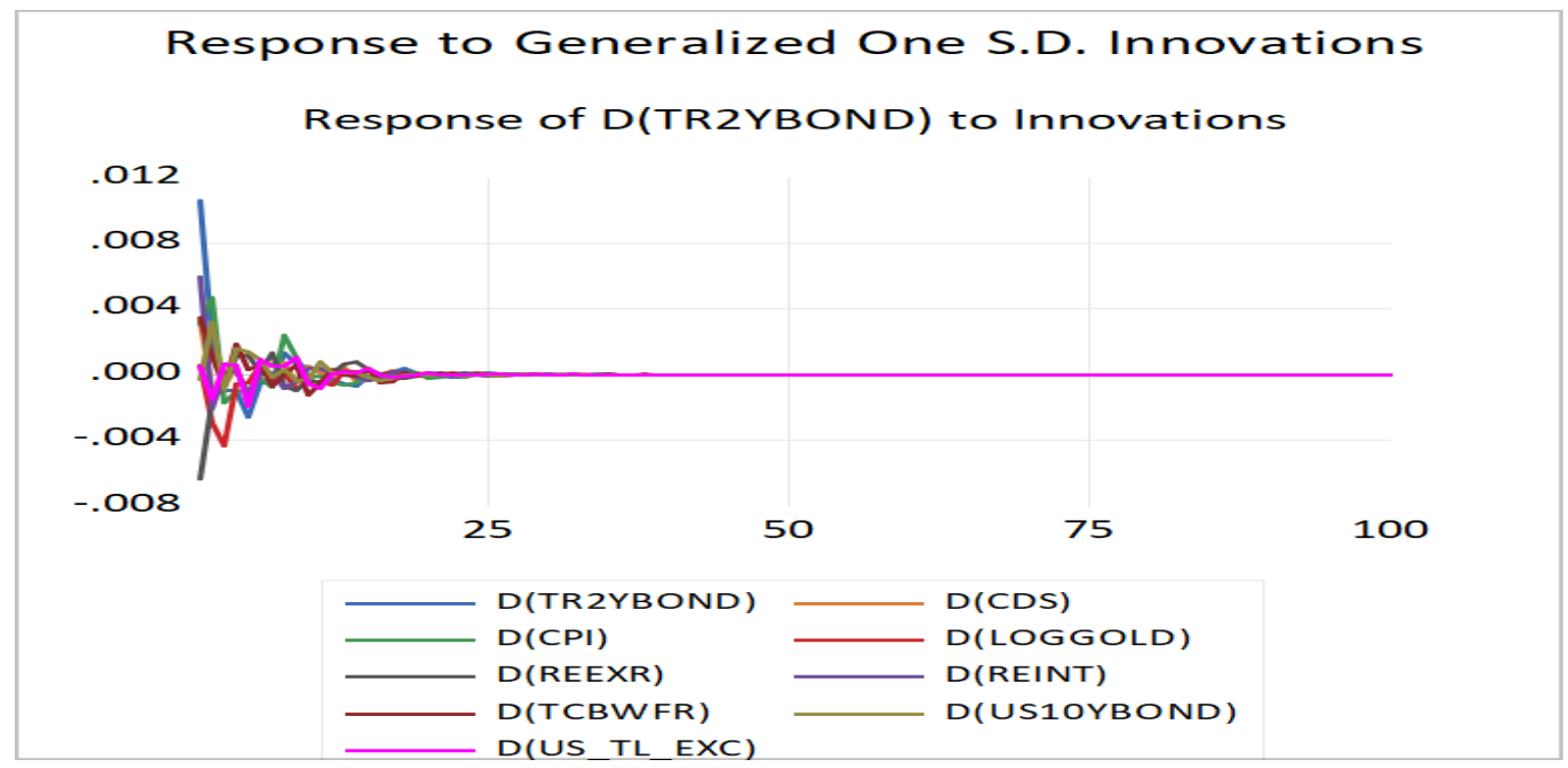

According to the historical decomposition results, it is observed that the disclosure percentage of inflation and real interest rates is high, except for the periods of interest shocks from advanced markets to emerging markets. In periods such as 2013 , 2015 and 2017 when financial fragilities increase, it is observed that the US 10-year interest rate and dollar rate variables are more effective. Apart from a sense of shock period shows that Turkey benchmark bond investors to focus on inflation and real returns. In times of crisis and shock, the US 10-year bond rates stand out.

Figure 5: Historical Decomposition Results

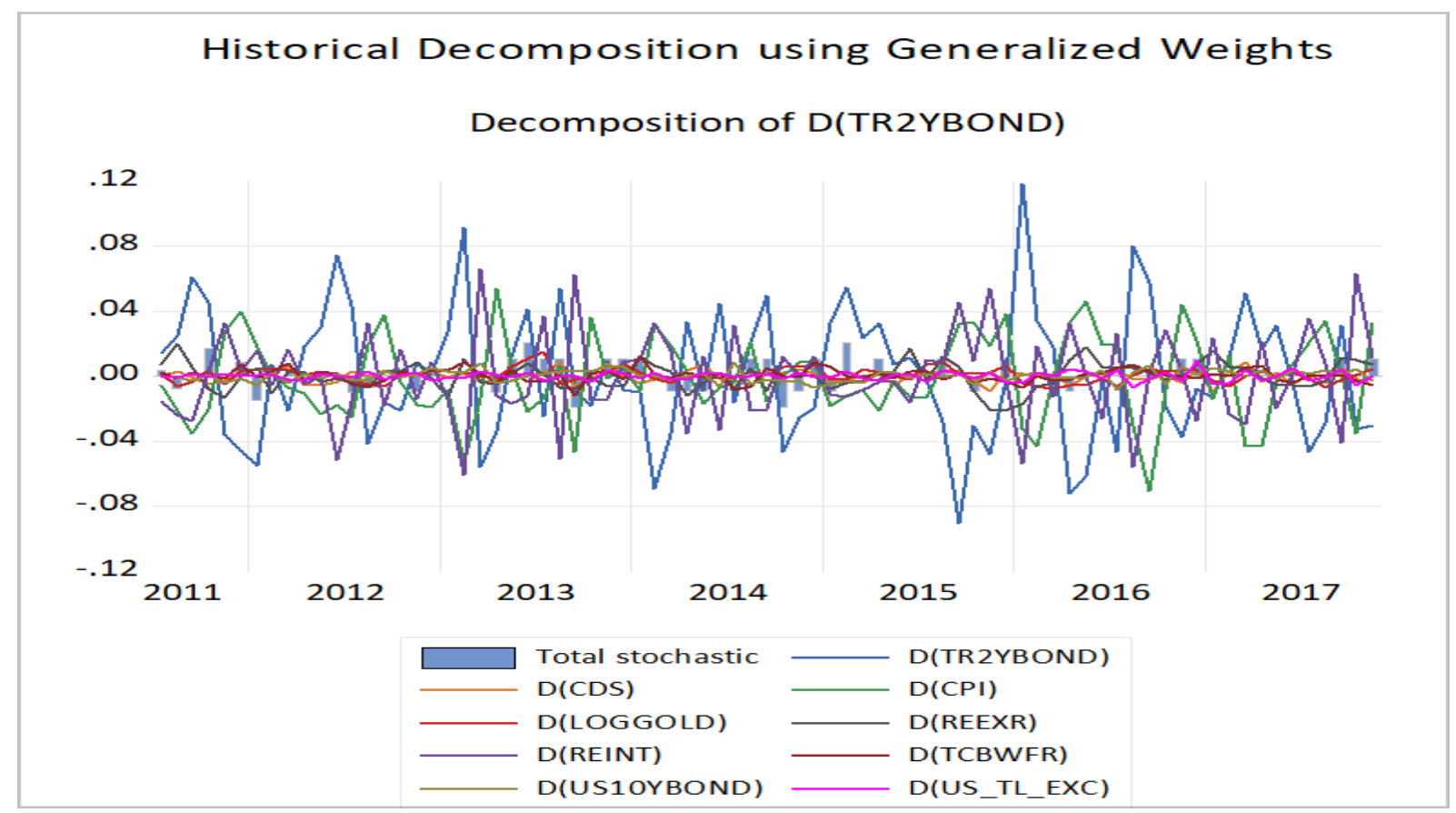




\section{CONCLUSION}

It was determined that the independent variables selected as a result of the structured models came into balance with the 2-year Turkish government bond benchmark interest rate in the short and long term-run. In addition, error correction terms for real interest rates and central bank weighted average funding cost variables are meaningful in short term.

When the factors affecting the benchmark bond rate are analyzed, it is seen that the variables that have the most effective and significant results on the benchmark rate are gold prices, inflation and the US 10-year bond interest. However, a causality relationship between gold prices and benchmark interest could not be determined. If we compare these results with the theoretical framework, inflationary expectations decreased the demand and price of the bond and increased the interest rate of the bond. According to the impulse-response functions, the short-term impact of gold and US 10-year bond yields; It can be considered in simulating the risk factor affecting the bond demand. Accordingly, with the increasing risk factor with the increase in US bonds, the demand and price of bonds decreased and their interest rates increased. According to the historical decomposition results, it was observed that the explanation effects of inflation and real interest rates increased during the periods of increase in interest rates.

According to the wald test; The causality in terms of gold, inflation, central bank weighted average funding cost, US 10-year bond interest rates and 2-year government bond interest rates from the USD / TL exchange rate were determined.

To briefly summarize the results in the combination of the results of all tests; The 2-year benchmark bond's interest for Turkey, gold as external factors and US 10-year bond yields inflation as internal factors and is sensitive to shocks in the real interest rate. Although the explanatory power of real interest rates is higher, according to causality tests, the Central Bank weighted average funding cost is more determinant on the benchmark rate, which is the market rate.

\section{REFERENCES}

Ahmad, N., Joriah M. ve Tajul, A. M. (2009), "Factors Influencıng Yield Spreads of The Malaysian Bonds", Asian Academy of Management Journal, Vol: 14, No: 2, Malaysia, pp. 95-114

Barışık, S., Kesikoğlu, F. (2006). "Türkiye'de Bütçe Açıklarının Makro EkonomikDeğişkenler Üzerine Etkisi (1987-2003 Var, Etki-Tepki Analizi, Varyans Ayrıştırması)." Ankara Üniversitesi Siyasal Bilgiler Fakültesi Dergisi, 61(4).

Barr, D.G. and B. Pesaran, (1997)," An Assessment of the Relative Importance of Realinterest Rates, Inflation, and Term Premium in Determining the Prices of Real andNominal U.K. Bonds," Review of Economics and Statistics, vol.79, 362-66.

Berument, H., \& Malatyal, K. (1999). Determinants of Interest Rates in Turkey, Discussion Papers No. 9902, Research and Monetary Policy Department, Central Bank of the Republic of Turkey.

Brooks, C. (2014). Introductory Econometrics for Finance (3rd edition), Cambridge

Calvo, G.A., L. Leiderman, and C.M. Reinhart, (1992)" Capital Inflows and Real Exchange RateAppreciation in Latin America: The Role of External Factors," IMF Staff Papers, 40. N.o 1,108-51.

Chowdhury, Z., Bayar Y.ve Kiliç C., (2013), "Effects of Major Macroeconomıc Indıcators On Emergıng Markets Bond Index", Afyon Kocatepe Üniversitesi iißBF Dergisi, Cilt:15, Sayı:2, Afyonkarahisar, ss. 15-30

Clare, A.and lekkos, I. (2000), "An Analysis of the Relationship Between İnternational Bond Markets”, London, pp. 1-39

Demir, M. \& Sever, E. (2008). Kamu İç Borçlanmasının Büyüme, Faiz ve Enflasyon Oranı Üzerindeki Etkileri, Elektronik Sosyal Bilimler Dergisi, 7(25), 170-196.

Dickey, D. A., \& Fuller, W. A. (1979). Distribution of the estimators for autoregressive time series with a unit root. Journal of the American Statistical Association, 74(366a), 427-431.

Dooley, M.P., E. Fernandez-Arias, and K. M. Kletzer, (1996)," Is the Debt-crisis History? Recent Private Capital inflows to Developing Countries," World Bank Economic Review,10, no 1, 27-50.

Fen, A.B., Lau S.Y., Lee C., Oon C., and Siew K.Y., (2014), “The Determınants of Malaysıa Government Bond Yields from Year 1996: Q1 to 2013: Q4", Unıversıty Tunku Abdul Rahman, Faculty of Busıness and Fınance Department of Fınance, Malaysia.

Frankel, J., (1994)," Why Haven't Interest Rates in Latin American and AsianCountries Converged to World Levels? Recent Portfolio Capital Inflows andStabilization" (unpublished).

Hsing, Y. (2015), "Determinants of The Government Bond Yield İn Spain: A Creditable Funds Model”, International Journal of Financial Studies, No:3, USA, pp. 342-350 
https://www.tcmb.gov.tr/, 01,09.2020

https://tr.investing.com/, 01.09.2020

Lebedeff, A. (2014), "The Spillover Effect of Macroeconomic News On Bond Yields-Evidence from Scandinavian Government Bond Markets and European Corporate Bond İndex", Master's Thesis, Department of Finance Aalto University School of Business, Finland.

Masatçı, K. \& Darıcı, B. (2006). Türkiye'de Faiz Oranlarının Belirlenmesinde İçsel ve Dışsal Faktörlerin Rolü. Akademik Fener Dergisi, (6), 1831.

Norliza, A. \& Muhammad, J. \& Masron, T. A. (2009). Factors Influencing Yield Spreads of the Malaysian Bonds. Asian Academy of Management Journal. 14.

Özgen, F. B., Güloğlu, B. (2004). "Türkiye'de İç Borçların İktisadi Etkilerinin VAR Tekniği İle Analizi," Metu Studies in Development, 1, 93-114.

Poghosyan, T. (2012), "Long-Run and Short-Run Determinants of Sovereign Bond Yields in Advanced Economies”, Fiscal Affairs Department, IMF Working Paper.

Rodionova, A. (2010), "Investigation of Factors Affecting the Russian Government Bond Yields", Higher School of Economics, Moscow.

Sachs, J. D., (1981)," The Current Account and the Macroeconomic Adjustment in the1970s," Brookings Papers on Economic Activities, 1, 201-268

Şenkesen, E. (2009), “Davranışsal Finans ve Yatırımcı Duyarlılığının Tahvil Verimi Üzerindeki Etkisi: IMKB Tahvil Ve Bono Piyasasında Bir Uygulama”, Doktora Tezi, İstanbul Üniversitesi Sosyal Bilimler Enstitüsü, İstanbul.

Yavuz, H. (2012), "Tahvil Piyasası Oynaklığının Belirlenmesinde Makroekonomik Değişkenlerin Oynaklığının Analizi”, Maliye Finans Yazıları, Yıl: 26, Sayı: 96, ss. 15-33

Ngo, T.\& Phong, N\& NGUYEN, A. (2020). Determinants of Vietnam Government Bond Yield Volatility: A GARCH Approach. The Journal of Asian Finance, Economics and Business. 7. 10.13106/jafeb.2020.vol7.no7.015.

Lin, F.L., Yang, S.Y., Marsh, T., \& Chen, Y.F. (2018). Stock and bond return relations and stock market uncertainty: Evidence from wavelet analysis. International Review of Economics \& Finance, 55, 285-294

Simoski, S. (2019) "A Keynesian Exploration of the Determinants of Government Bond Yields for Brazil, Colombia, and Mexico" Masters of Science in Economic Theory and Policy. 16. https://digitalcommons.bard.edu/levy ms/16 